\title{
Genetic and Molecular Mechanisms of the Congenital Defects in Glucose Phosphate Isomerase Activity: Studies of Four Families
}

\author{
A. KAHN $\left({ }^{(24)} *\right.$ J. P. M. VAN BIERVLIET, $\dagger$ J. L. VIVES-CORRONS, $\ddagger$ D. COTTREAU,* AND \\ G. E. J. STAAL \\ * Institut de Pathologie Moléculaire, INSERM U. 129, Paris, France; † Section of Medical Enzymology, \\ Department of Hematology, State University Hospital, Utrecht, The Netherlands; and $\ddagger$ Postgraduate School of \\ Hematology, Hospital Clinico y provincial, University of Barcelona, Barcelona, Spain
}

\section{Summary}

Four patients with hereditary glucose phosphate isomerase (GPI) deficiency and their parents have been studied by means of various enzymatic, immunologic, electrophoretic, and stability methods. The four defective mutants enzymes (identified here as "GPI Barcelona," "GPI Utrecht," "GPI Nijmegen," and "GPI Kortrijk") were antigenically identical with normal enzyme as judged by double immunodiffusion and microcomplement fixation tests. Immunologic specific activity (i.e., the ratio of enzyme activity to antigen concentration) was slightly lowered for three variants (between 60 and $75 \%$ of normal). The various methods used allowed us to establish that all of the patients were heterozygous for two different mutated alleles inherited from each parent. One of them was a silent allele which did not seem to code for any enzymatic cross-reacting material; the other mutated gene coded for a structurally modified glucose phosphate isomerase subunit.

In two parents heterozygous for a structurally modified gene, only two enzymatic forms were detected, even in the young cells synthesizing actively proteins such as granulocytes: one was the normal homodimer, and the other corresponded to the heterodimer "normal subunit-mutant subunit"; the mutant homodimer was not detected. The assumption that, in these heterozygotes, the mutant subunit dimerized more easily with a normal subunit than with another mutant subunit could be proposed. In contrast, the three expected enzyme forms were detected in the leukocytes from a woman heterozygous for GPI Nijmegen.

From these results the defect in activity observed in the patients could be explained in the following way: $50 \%$ of the defect was due to the inheritance of a silent gene. The decrease below $50 \%$ of the residual activity in red cells was due to the molecular instability of the mutant enzyme associated in three cases (GPI Barcelona, GPI Utrecht, and GPI Kortrijk) with the decreased immunologic specific activity.

\section{Speculation}

In spite of the relatively high frequency of the mutations which are responsible for a silent GPI structural gene, GPI deficiency due to the inheritance of two silent genes has never been described. It can be speculated that the homozygous state of such a mutation, which would lead to null enzyme activity in all the tissues, could be lethal. As in most cases of genetic disorders due to silent genes, the nature of the mutation involved is unknown. A deletion, a polar mutation, a structural mutation leading to a highly labile product, or a cis-dominant regulator mutation are the different genetic hypotheses which could be put forward.

The congenital defect in glucose phosphate isomerase activity (EC. 5.3.1.9) represents the third most frequent enzymopathy in red cells. Since its discovery by Baugham et al. $(3,4)$ in 1967 , at least 25 new cases have been described.

Glucose phosphate isomerase is a dimeric molecule (7); its structural gene is autosomal, located on the chromosome $19(14$, 17). A single genetic form of glucose phosphate isomerase is synthesized in all the cells of the organism $(2,7,16)$. Consequently, the structural mutation of this enzyme will be expressed in all the tissues. Since the mutations usually result in increased lability of the enzyme, however, the defect in activity will be maximum in the aged and anucleated cells, such as the red cells (1). Thus, the pathologic consequences of the enzyme deficiency will involve mainly the red blood cells, leading to chronic hemolysis. Sometimes, however, glucose phosphate isomerase deficiency can be responsible for some metabolic disturbances in various tissues, as demonstrated by Van Biervliet et al. (19) in the case of the patient with "GPI Utrecht." The aim of the present work was to elucidate the genetic and molecular mechanisms of the defect in glucose phosphate isomerase activity detected in different families.

\section{MATERIALS AND METHODS}

All the substrates, coenzymes, and auxiliary enzymes were purchased from Boehringer-Mannheim or Sigma CC. Tetrazolium salt MTT and phenazine methosulfate were furnished by Sigma CC. Ampholines of $\mathrm{pH}$ range 9-11 were furnished by LKB. Isoelectrofocusing was performed in a ISCO model 212 column, or in a Biorad model $150 \mathrm{~A}$ electrophoresis cell. Agarose was from l'Industrie biologique française," acrylamide and bisacrylamide from Eastman Kodak, and starch for gel electrophoresis from Connaught. Enzymatic reactions were measured at $30^{\circ}$ in Zeiss PMQ II or Gilford 2400 spectrophotometers. The reagents used in the microcomplement fixation tests came from l'Institut Pasteur in Paris.

\section{BLOOD SAMPLES}

Blood was anticoagulated with acid citrate dextrose (formula A) in plastic tubes. Leukocytes, platelets, and red cells were separated by methods previously reported (10).

\section{ENZYME ASSAYS}

The standard assay of glucose phosphate isomerase activity was performed backward (fructose-6-phosphate $\rightarrow$ glucose-6phosphate), according to the method of Beutler (6). Hemoglobin concentration was measured by the cyanmethemoglobin method, and protein concentration by the Lowry method (13). The results were expressed in international units per $g$ hemoglobin or per mg protein. 


\section{ELECTROPHORESIS AND ELECTROFOCUSING STUDIES}

Starch gel electrophoretic study of the mutant glucose phosphate isomerase variants was performed according to the method of Detter et al. (7), in Tris-citrate buffer, pH 8. Isoelectrofocusing was performed either in sucrose gradient or in columns $(5 \times 120 \mathrm{~mm})$ of $5 \%(\mathrm{w} / \mathrm{v})$ acrylamide containing $1 \%$ ampholine, $\mathrm{pH} 9-11$, and $0.2 \mathrm{IU} / \mathrm{ml}$ yeast glucose- 6 -phosphate dehydrogenase (9). The anodic tank, at the top of the columns, contained $1 \%(\mathrm{v} / \mathrm{v})$ acetic acid, and the cathodic tank, at the bottom, $4 \%(\mathrm{v} / \mathrm{v})$ ethanolamine. Glucose phosphate isomerase activity was specifically revealed on the gels as described elsewhere (10).

\section{SEARCH FOR ANTIGENIC DIFFERENCES BETWEEN WILD AND MUTANT ENZYMES}

Normal glucose phosphate isomerase was totally purified from human leukocytes as previously reported (5). Two different lots of monospecific anti-glucose phosphate isomerase sera were grown in rabbits; their titers were, respectively, 120 and 250 IU precipitated enzyme per $\mathrm{ml}$ antiserum (5).

The double immunodiffusion experiments were performed according to the method of Ouchterlony (15); these compared the immunoprecipitate lines obtained with normal and mutant leukocyte enzymes.

Microcomplement fixation tests were performed according to the method of Levine and Van Vunakis (11), and slightly modified in that the total reaction mixture was $1.4 \mathrm{ml}$ instead of $7 \mathrm{ml}$. In these experiments the antigen source was either leukocyte crude extracts or purified preparations (5). Lyophilized guinea pig serum (as complement source) was diluted 1,320 times and antiserum (first lot) was diluted 18,000 times. A range of enzyme dilutions having total enzyme activity from $2 \times 10^{-3}$ to 40 $\times 10^{-3} \mathrm{IU}$ was used.

\section{IMMUNOLOGIC TITRATIONS}

Glucose phosphate isomerase-related antigen concentration was measured by electroimmunodiffusion, according to a method we have previously described (5) (Fig. 1). The ratio of the enzyme activity to the antigen concentration (i.e., the "immunologic specific activity") was determined from these experiments by plotting the enzyme activity versus the surfaces of the immunoprecipitate peaks; immunologic specific activity is proportional to the slope of the straight line obtained, and was expressed as a percentage of the value found for the enzyme from fresh leukocyte extracts studied in the same experiment (Fig. 1).

\section{HEAT STABILITY STUDY}

Stability to heat of the enzyme activity from normal and mutant enzymes was appraised at $48^{\circ}$ in $100 \mathrm{mM}$ Tris- $\mathrm{HCl}$ buffer, pH 8, containing $1 \mathrm{mM} \epsilon$-aminocaproic acid, $1 \mathrm{mM}$ diisopropylfluorophosphate, $1 \mathrm{mM}$ EDTA, and $2 \mathrm{mg} / \mathrm{ml}$ bovine albumin (10).

\section{PATIENTS}

Our studies involved the families in which the variants GPI Barcelona, GPI Utrecht, GPI Nijmegen, and GPI Kortrijk have been discovered. Clinical observations and biochemical characterizations have been described in previous papers $(10,20-22)$, or will be published elsewhere (18). In order to make the account of the results easier, we will designate the patients and their families by the name of the variant.

\section{RESULTS}

\section{SEARCH FOR ALTERED ANTIGENICITY OF MUTANT GLUCOSE PHOSPHATE ISOMERASE VARIANTS}

The double immunodiffusion tests showed patterns of immunologic complete identity between normal enzyme and all the four variants. This result was similar with either antiserum lot. The microcomplement fixation curve of GPI Nijmegen was identical with that of normal enzyme. With GPI Barcelona, GPI Utrecht, and GPI Kortrijk the maximum amount of complement fixed was normal (about $80 \%$ ). The curves, however, were slightly shifted to the left, this maximum fixation being reached with about $7.5 \times 10^{-3}$ IU Barcelona or Utrecht variants, $6.3 \mathrm{IU}$ GPI Kortrijk and $10 \times 10^{-3} \mathrm{IU}$ normal enzymes (Fig. 2 ). The same results were obtained with either lot of antiserum, whether leukocyte crude extracts or purified preparations were used.

\section{ENZYMATIC AND IMMUNOLOGIC TITRATIONS}

The results of the enzymatic and immunologic titrations of glucose phosphate isomerase from the blood cells of the patients and their parents are summarized in Tables $1,2,3$, and 4.

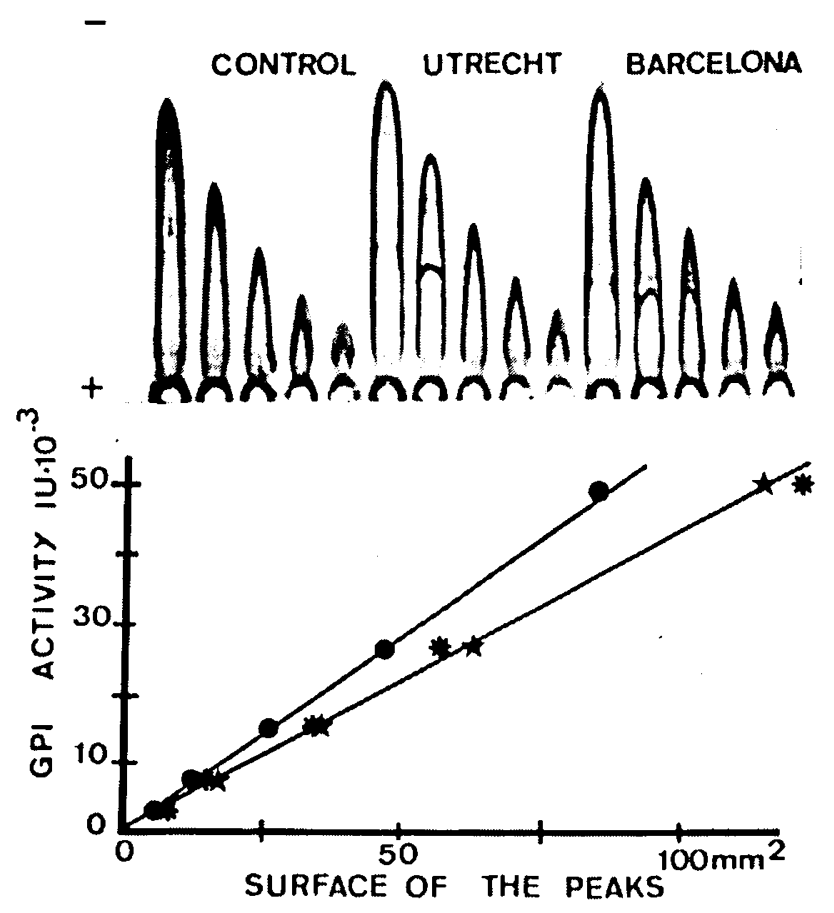

Fig. 1. Electroimmunodiffusion of leukocyte glucose phosphate isomerase (GPI) from a normal control subject, the patient with GPI Utrecht, and the patient with GPI Barcelona. The graphic representation of this experiment is shown below the photograph of the electroimmunodiffusion plate. $\bullet-\bullet$ : normal control subject; $* \longrightarrow$ : GPI Utrecht; $\star —$ : GPI Barcelona.

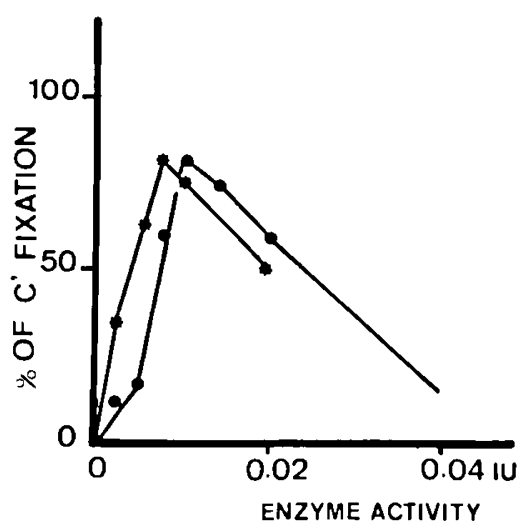

Fig. 2. Microcomplement ( $\left.C^{\prime}\right)$ fixation test of purified glucose phosphate isomerase (GPI) from normal control and from the patient with GPI Utrecht. In this experiment the final dilution of the anti glucose phosphate isomerase serum (lot no. 1) was 1:18,000 and that of complement was $1: 1,320$. The symbols are the same as in Figure 1 . 
Table 1. Glucose phosphate isomerase barcelona ${ }^{1}$

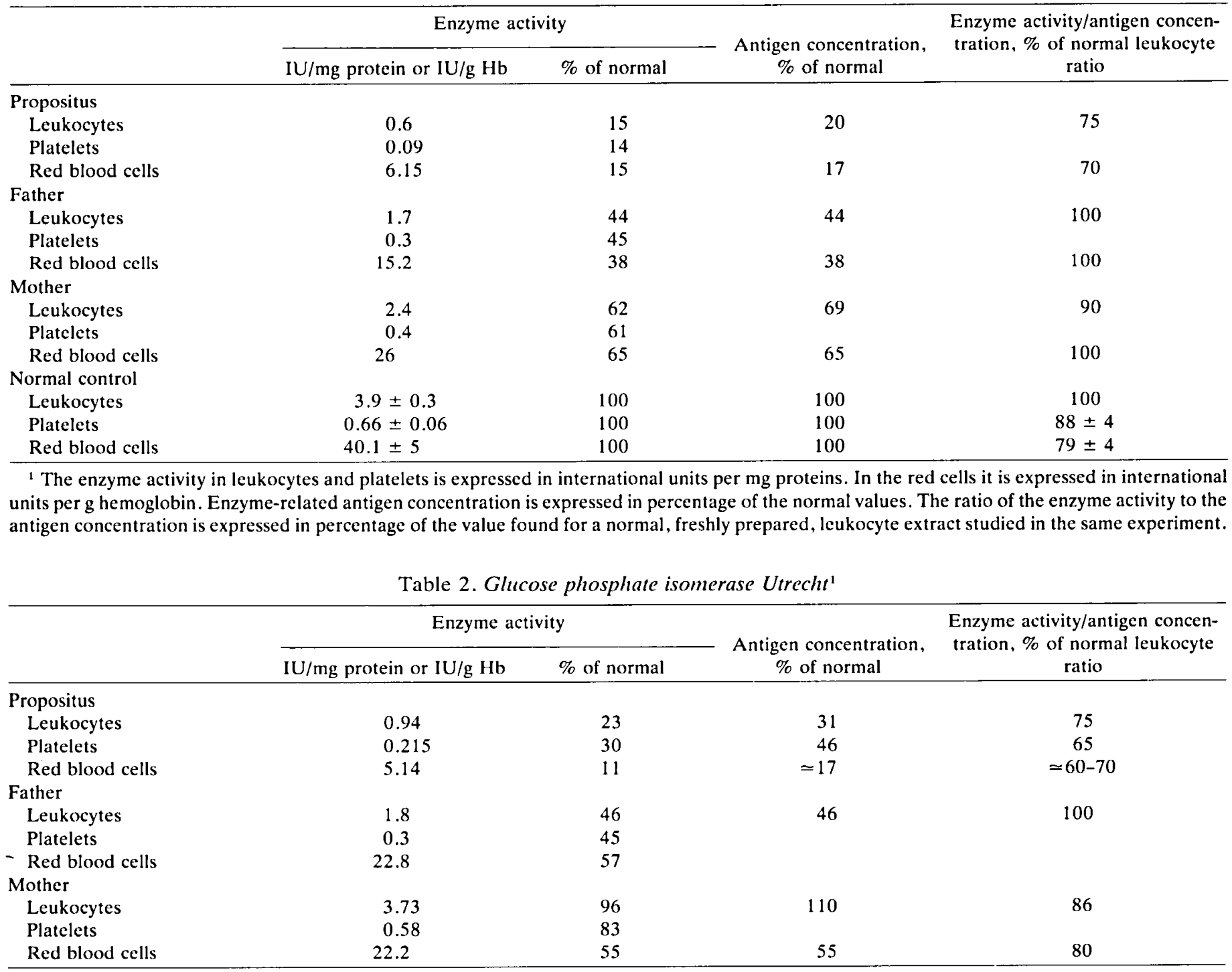

1 For explanation of units of measure, see footnote 1 of Table 1.

Table 3. Glucose phosphate isomerase Nijmegen ${ }^{1}$

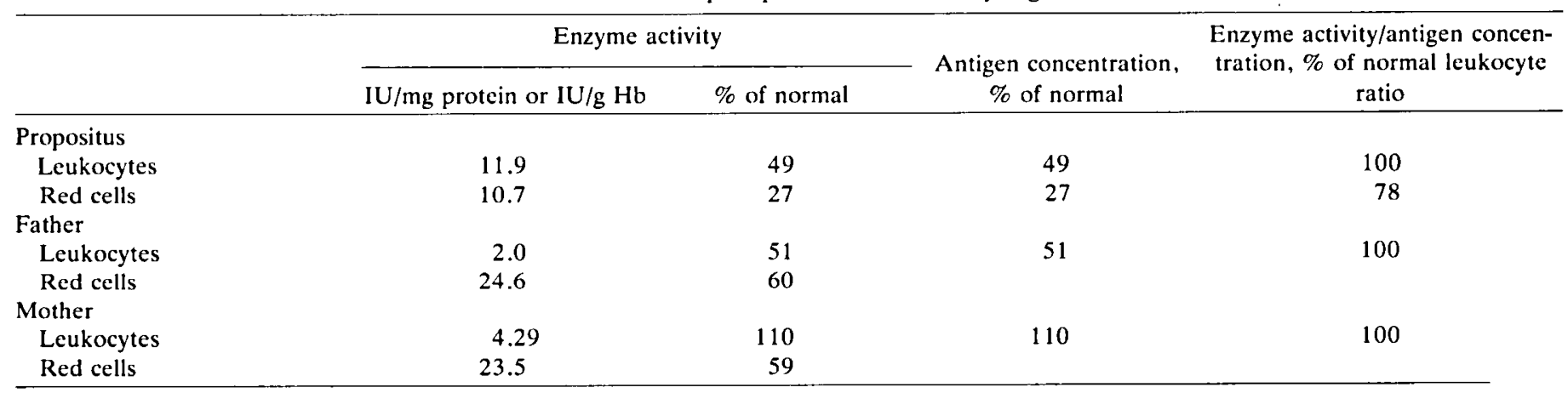

' For explanation of units of measure, see footnote 1 of Table 1.

Families of Patients with Variants Barcelona, Utrecht, and Nijmegen. In the patient with GPI Barcelona, immunologic specific activity of the defective enzyme was about $75 \%$ of normal (Fig. 1); residual enzyme activity was about $15 \%$ of normal in the leukocytes, platelets, and red cells. In the patient with GPI Utrecht, immunologic specific activity was reduced to about $75 \%$ of normal, as well (Fig. 1). The defect in activity was $23 \%$ of normal in the leukocytes, $30 \%$ in the platelets, and $17 \%$ in the red cells. In the patient with GPI Nijmegen, immunologic specific activity was normal. Enzyme activity was about $50 \%$ of normal in the leukocytes and $27 \%$ in the red cells.

In all the three families the patients' fathers had both glucose phosphate isomerase activity and antigen concentration decreased about by half in the leukocytes and the erythrocytes. Consequently, immunologic specific activity was normal in all of these cases. In the mothers of the Utrecht and Nijmegen patients, enzyme activity was nearly normal in the leukocytes, the defect in activity reaching $55 \%$ and $59 \%$ of normal in the red 
Table 4. Glucose phosphate isomerase Kortrijk ${ }^{1}$

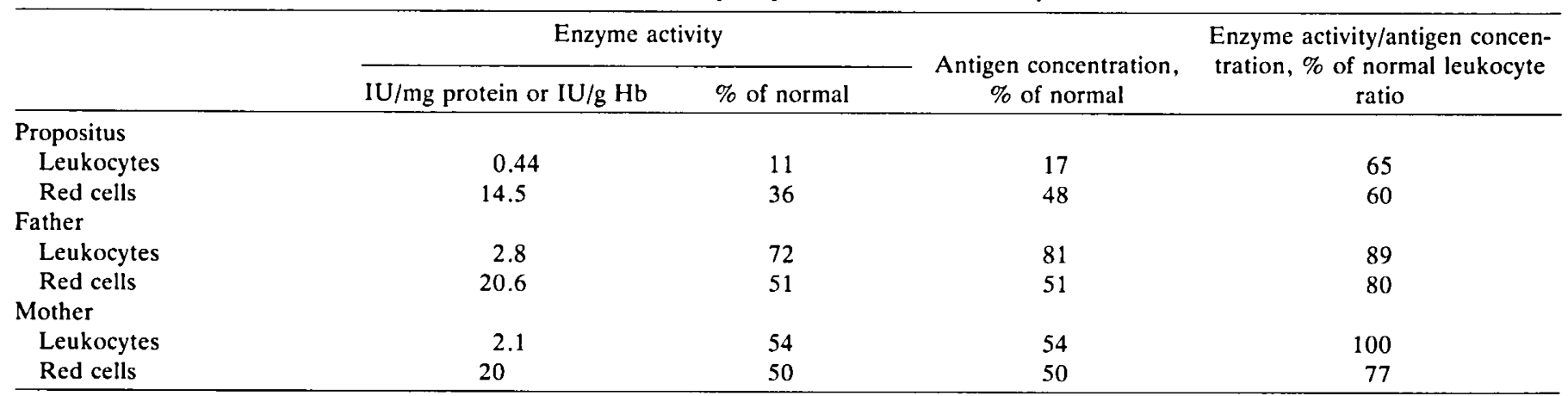

${ }^{1}$ For explanation of units of measure, see footnote 1 of Table 1.

blood cells. Enzyme activity ranged from $62-65 \%$ of normal in all the blood cells of the mother of the Barcelona patient. Immunologic specific activity of glucose phosphate isomerase was nearly normal in all the blood cells of these women.

Family of Patient with GPI Kortrijk. In the patient, immunologic specific activity of the defective enzyme was decreased to $65 \%$ of normal in the leukocytes. The defect, in activity as well as in enzyme-related antigen, was apparently more severe in the leukocytes $(11 \%$ and $17 \%$ of normal, respectively) than in the red cells ( $36 \%$ and $48 \%$ ).

In the father, glucose phosphate isomerase activity and enzyme-related antigen concentration were slightly decreased in the leukocytes and reduced by half in the red cells. These values were decreased in parallel by about half in the red cells. These values were decreased in parallel by about half in the leukocytes as well as in the red cells from the mother.

\section{ELECTROPHORETIC AND ELECTROFOCUSING DATA (FIG. 3)}

Electrophoretic and electrofocusing patterns of glucose phosphate isomerase were normal in the family of the Utrecht patient.

In the patient with GPI Barcelona, a single enzyme form was detected, the isoelectric point of which was 9.55. The mother's blood cells exhibited two forms, one having normal electrophoretic migration and normal isoelectric point (pI: 9.22), the other having a migration intermediate between that of normal enzyme and that of the defective enzyme from the propositus. Glucose phosphate isomerase from the father's blood cells had normal electrophoretic mobility and normal isoelectric point.

The patient with GPI Nijmegen showed a single anodic active band (pI: 8.95) in all of the blood cells. The mother's leukocytes contained three active forms: one was identical with that of the patient cells, the second had intermediate electrophoretic mobility, and the third had normal electrophoretic migration and isoelectric point. The father exhibited a single enzyme form, with normal mobility in both the white blood cells and the red cells (Figs. 4 and 5).

By starch gel electrophoresis both the red cells and the leukocytes from the patient with GPI Kortrijk showed a single fast migrating active band (Fig. 6). Isoelectrofocusing tests, however, were unable to detect any modification of isoelectric point of this defective enzyme. Electrophoretic mobility was normal in the mother. In the father, two active bands were detected. One, predominant in the white blood cells and less important in the red cells, had a migration intermediate between that of enzyme from the patient and a control subject; the other band had normal migration.

\section{HEAT STABILITY STUDIES}

Stability to heat of the defective enzyme from the four patients was decreased in the leukocytes, as well as in the red cells. In the leukocytes, the curves $\log \mathrm{V} / \mathrm{VO}=\mathrm{f}$ (heating time) were biphasic

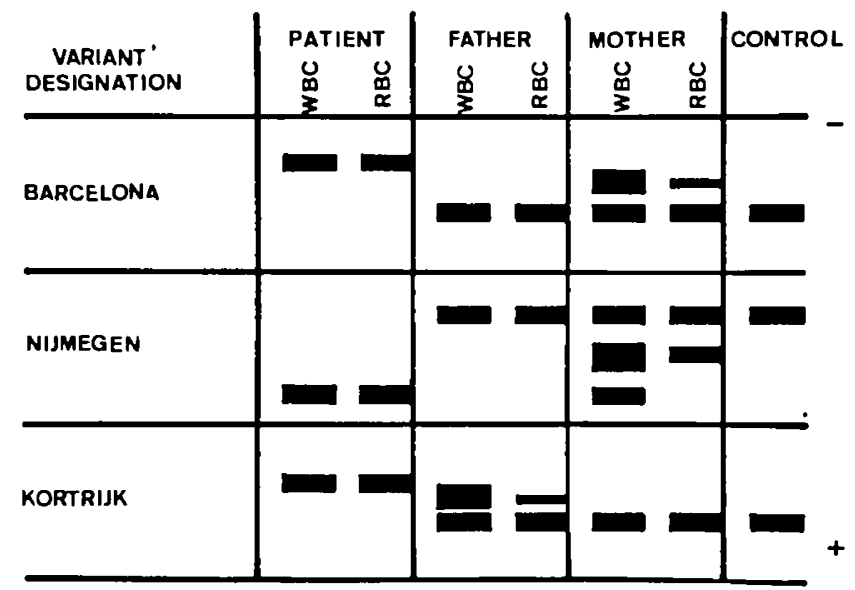

Fig. 3. Schema of the electrophoretic migration in starch gel of glucose phosphate isomerase active forms from the patients and their families. WBC: white blood cells, RBC: red blood cells.

in the mothers of the patients with the variants Barcelona, Utrecht, and Nijmegen, and in the father of the fourth patient (with GPI Kortrijk); these curves were normal in the other parents (Fig. 7).

\section{DISCUSSION}

The results of the double immunodiffusion and microcomplement fixation analyses seem to indicate that, with respect to the different lots of antiwild enzyme used, the four defective enzymes tested herein and normal glucose phosphate isomerase were antigenically identical.

The complete identity found by immunodiffusion, indeed, signified that the antiserum used recognized the same antigenic determinants on the mutant and normal enzymes $(8,12)$. In microcomplement fixation tests, the variants Barcelona, Utrecht, and Kortrijk fixed as much complement as normal enzyme. The fixation curves plotted versus the enzyme activity of the dilutions, however, were shifted to the left. This finding signified only that the same antigen amount, which corresponds to the maximum fixation, had an enzyme activity lower for the mutant enzymes than for normal glucose phosphate isomerase. By contrast, according to Levine and Van Vunakis (11), the reduced number of antigenic determinants recognized by the antiserum would result in a vertical shift of the curve and a qualitative alteration of these antigenic determinants would result in a shift to the right. The fixation curve obtained with GPI Nijmegen was totally identical with that obtained with normal enzyme.

This antigenic identity between normal and mutant glucose phosphate isomerase enables the accurate measurement of en- 


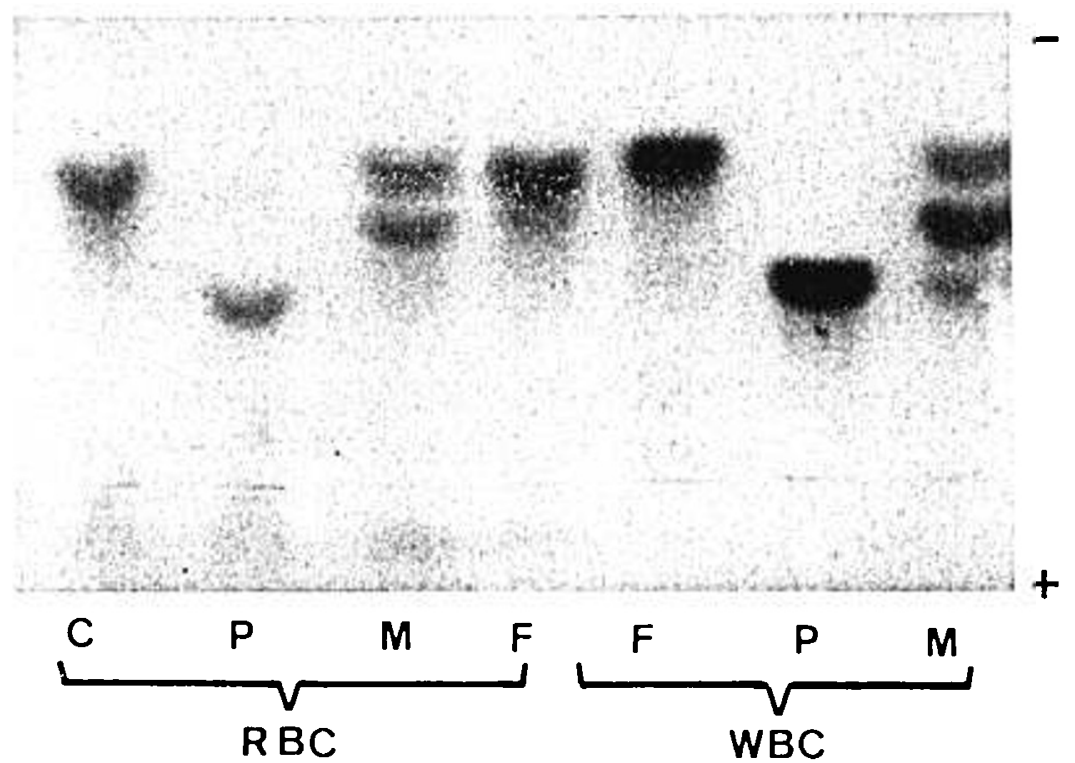

Fig. 4. Starch gel electrophoresis of glucose phosphate isomerase (GPI) from the patient with GPI Nijmegen and his family. WBC: white blood cells; RBC: red blood cells; C: control; P: patient; M: mother; F: father.

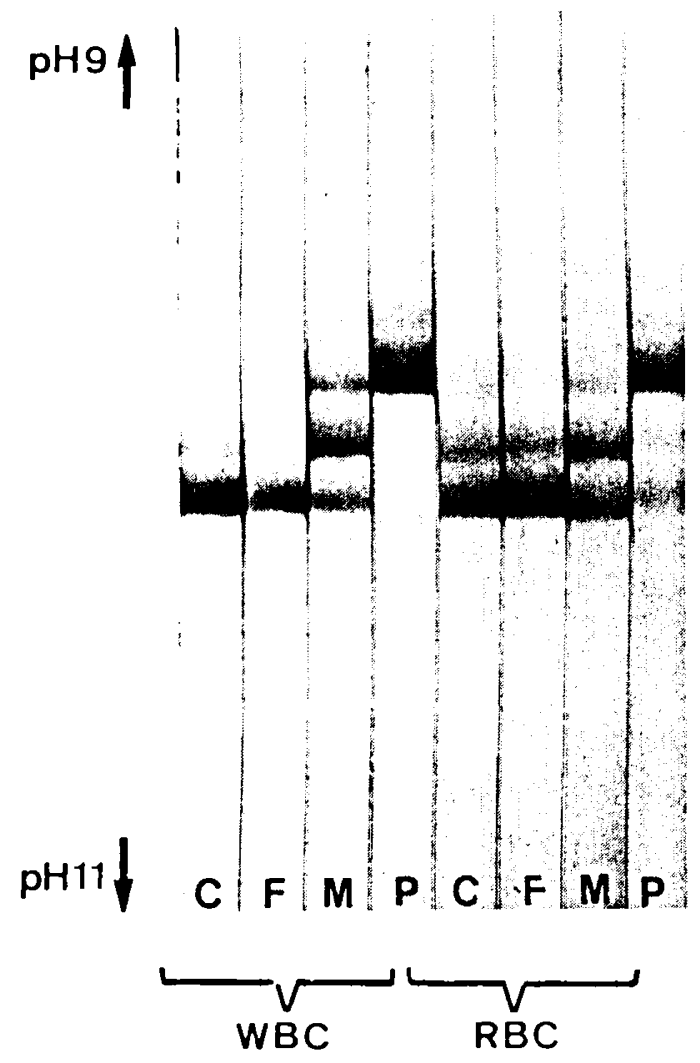

Fig. 5. Isoelectrofocusing in acrylamide-ampholine slab gel of glucose phosphate isomerase from the patient with GPI Nijmegen and his family. For explanation of symbols, see legend to Figure 4.

zyme-related antigen concentration and immunologic specific activity of the mutant enzyme variants with respect to normal enzyme. These immunologic titrations gave, mainly, two pieces of information. (1) All three fathers of the patients with the variants Barcelona, Utrecht, and Nijmegen, together with the mother of the patient with GPI Kortrijk, exhibited a parallel reduction of $50 \%$ of both enzyme activity and antigen concentration in the leukocytes and the red cells. Consequently, the most likely hypothesis was that these subjects were heterozygous

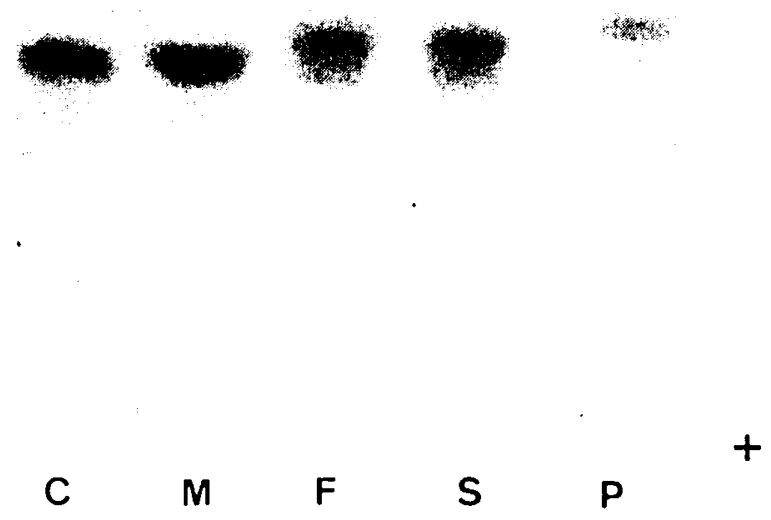

Fig. 6. Starch gel electrophoresis of leukocyte glucose phosphate isomerase (GPI) from the patient with GPI Kortrijk and his family. C: control; M: mother; F: father; S: son; P: patient.

for a silent gene that did not code for any cross-reacting material. (2) Immunologic specific activity of three variants was slightly (but reproductibly) decreased: to $75 \%$ of normal for the variants Barcelona and Utrecht and to $60-65 \%$ of normal for GPI Kortrijk. Such a decrease of the ratio of the enzyme activity to the antigen concentration explained a part of the observed defect in glucose phosphate isomerase activity.

The electrophoretic and electrofocusing data obtained in the patients and their parents allowed the genetic determinism of the enzyme activity deficiency found in the patients with GPI Barcelona, GPI Nijmegen, and GPI Kortrijk to be specified. These three variants showed abnormal electrophoretic mobilities: fast for the variants Barcelona and Kortrijk and slow for the variant Nijmegen. No abnormal active band was detected in the fathers of the patients with the variants Barcelona and Nijmegen and in the mother of the patient with GPI Kortrijk, supporting the concept of the silent allele in these subjects. The mother of the patient Barcelona and the father of the patient Kortrijk exhibited an additional fast migrating active band predominant in the leukocytes and minor in the red cells; this additional band with an intermediate migration probably corresponded to the 


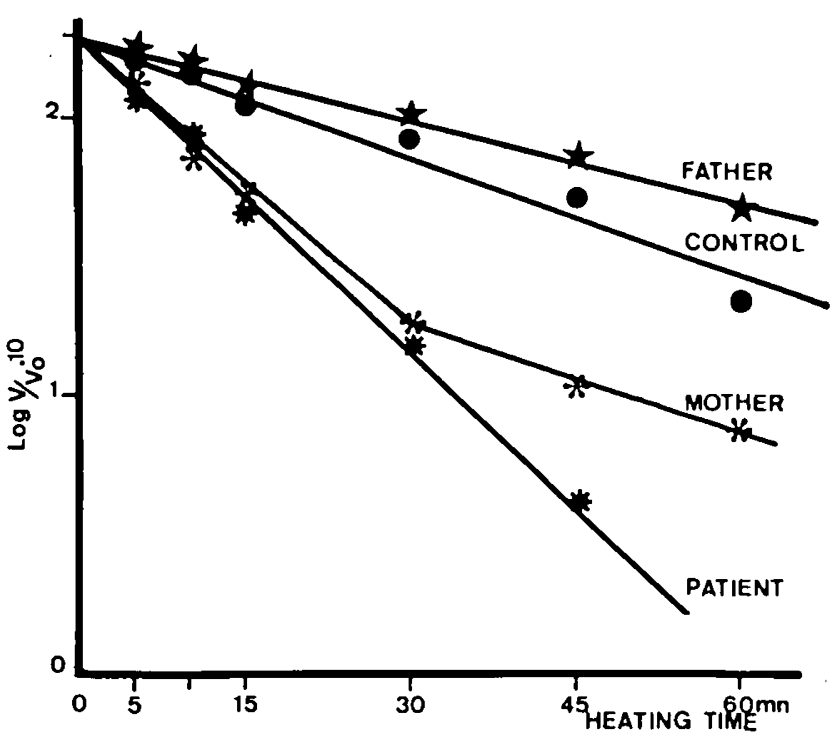

Fig. 7. Heat stability at $48^{\circ}$ of glucose phosphate isomerase (GPI) from the patient with GPI Utrecht and his family. Leukocyte extracts were diluted in a $100 \mathrm{mM}$ Tris- $\mathrm{HCl}$ buffer, $\mathrm{pH} 8$, containing $1 \mathrm{mM}$ $\beta$-mercaptoethanol, $1 \mathrm{mM}$ EDTA, $1 \mathrm{mM} \epsilon$-aminocaproic acid, and 1 $\mathrm{mM}$ diisopropylfluorophosphate.

heterodimer "normal subunit-mutant subunit." The mutant homodimer was not detected, even in the leukocytes, which are young cells actively synthesizing proteins. The only instability of the mutant homodimer did not seem to be sufficient to explain its absence in the leukocytes of the heterozygotes, since the patients' leukocytes showed a noticeable amount of this form. The hypothesis that the dimerization of the mutant subunit with a normal subunit is favored with respect to the formation of the mutant homodimer can be put forward. By contrast, in the mother of the patient with the variant Nijmegen, the three forms (i.e., normal homodimer, heterodimer, and mutant homodimer) were easily distinguished by either starch gel electrophoresis or electrofocusing (Figs. 4 and 5). In these observations the mutant homodimer, being the most unstable form, disappeared totally from the old and anucleated cells such as the red blood cells.

In the case of GPI Utrecht, whose electrophoretic mobility was normal, the thermal stability tests with the leukocyte enzymes allowed confirmation of the facts that the father was heterozygous for a silent gene and the mother for a structurally abnormal enzyme; the heat inactivation curve of the father's leukocyte enzyme was totally identical with that of normal glucose phosphate isomerase. In the mother, two forms could be clearly distinguished according to their stability: one was as unstable as GPI Utrecht and the other as stable as normal enzyme (Fig. 7).

From the results reported above, the defect in enzyme activity in the patients' red cells could be explained in the following way: all of the patients were heterozygous for two different mutated alleles inherited from each parent. One of them was a silent gene, and the other a structurally modified gene. Fifty percent of the defect in activity was due to the inheritance of the silent gene. In the patient with GPI Nijmegen the decrease below $50 \%$ of residual activity was only due to instability of the mutant enzyme. In the other cases the decrease below $50 \%$ of residual activity was both explained by decreased immunologic specific activity and molecular instability of the mutant variants.

The fact that the defect in activity associated with GPI Kortrijk was apparently more pronounced in the leukocytes than in the red cells should be interpreted in function of the high reticulocyte count (as high as $70 \%$ ) found in the patient: if it is possible to express the residual leukocyte enzyme activity as a percentage of normal, this is not correct for red cell glucose phosphate isomerase since the red cells from this patient are far younger than those from a normal control with a normal reticulocyte count.

It should be noted that in all of the cases studied in this paper a single molecular form exists in the patients, since the silent genes inherited from one of the parents did not seem to code for any protein recognized antigenically or enzymatically as glucose phosphate isomerase. Consequently, it seems to be correct to characterize these variants by a distinct designation, in contrast with the cases in which the defect results from the inheritance of two different structurally modified enzymes.

In conclusion, the combination of various immunologic, electrophoretic, and stability studies allows the accurate analysis of the genetic determinism and the molecular mechanism of the congenital defects in glucose phosphate isomerase activity.

\section{CONCLUSION}

The genetic and molecular mechanisms of the defect in enzyme activity have been studied in four patients with congenital nonspherocytic hemolytic anemia due to erythrocyte GPI deficiency. The combination of various immunologic, electrophoretic, and stability studies allowed us to establish that all the patients were heterozygous for two different mutated alleles inherited from each parent; one of them was a silent gene while the other coded for structurally modified GPI subunits.

\section{REFERENCES AND NOTES}

1. Arnold, H., Blume, K. G., Engelhardt, R., and Löhr, G. W.: Glucosephosphate isomerase deficiency: Evidence for in vivo instability of an enzyme variant with hemolysis. Blood, 41: 691 (1973)

2. Arnold, H., Hoffmann, A., Blume, K. G., Engelhardt, R., and Löhr, G. W.: Zür Frage gewebespezifischer Isoenzyme der Glucosephosphatisomerase des Menschen. (Concerning tissue-specific isoenzymes of glucosephosphate isomerase in man.) Klin. Wochenschr., 52: 149 (1974).

3. Baughan, M. A., Valentine, W. N., Paglia, D. E., Ways, P. O., Simon, E. R. and Demarsh, Q. B.: Hereditary anemia associated with glucose phosphate isomerase deficiency: A new enzyme defect in human erythrocytes. Blood, 30: 850 (1967).

4. Baughan, M. A., Valentine, W. N., Paglia, D. E., Ways, P. O., Simon, E. R., and Demarsh, Q. B.: Hereditary hemolytic anemia with glucose phosphate isomerase (GPI) deficiency, a new enzyme defect of human erythrocytes. Blood, 32: 236 (1968).

5. Bertrand, O., Kahn, A., Cottreau, D., and Boivin, P.: Human leukocyte glucose phosphate isomerase: Purification by affinity elution and immunological study. Biochimie, 58: 261 (1976).

6. Beutler, E.: Red Cell Metabolism, A Manual of Biochemical Methods (Grune \& Stratton, New York, 1971).

7. Detter, J. C., Ways, P. O., Giblett, E. R., Hopkinson, D. A., Povey, S., and Harris, H.: Inherited variations in human phosphohexose isomerase. Ann. Hum. Genet., 3l: 329 (1968)

8. Gassef, F., and Gasser, C.: Immunological relations among lactic acid dehydrogenases in the genera Lactobacillus and Leuconostoc. J. Bacteriol., I06: 113 (1971).

9. Harrison, R. A. P.: The detection of hexokinase, glucose phosphate isomerase and phosphoglucomutase activities in polyacrylamide gels after electrophoresis: A novel method using immobilized glucose 6 phosphate dehydrogenase. Anal. Biochem., 61: 500 (1974).

10. Kahn, A., Vives-Corrons, J. C., Bertrand, O., Cottreau, D., Marie, J., and Boivin, P.: Glucose phosphate isomerase deficiency due to a new variant (GPI Barcelona) and to a silent gene: Biochemical, immunological and genetic studies. Clin. Chim. Acta, 66: 145 (1976).

11. Levine, L., and Van Vunakis, H.: Micro complement fixation. Methods Enzymol., 11: 928 (1967).

12. London, J., and Kline, K.: Aldolase of lactic acid bacteria: A case of history in the use of enzyme as an evolutionary marker. Bacteriol. Rev., 37: 453 (1973).

13. Lowry, O. H., Rosebrough, N. J., Farr, A. L., and Randall, R. J.: Protein measurement with the Folin phenol reagent. J. Biol. Chem., 193: 265 (1951).

14. Mc Morris, F. A., Chen, T. R., Ricciuti, F., Tischfield, J., Creagan, R., and Ruddle, F.: Chromosome assignments in man of the genes for two hexosephosphate isomerases. Science, 179: 1129 (1973).

15. Ouchterlony, O.: Diffusion in gel: Methods for immunological analysis. Progr. Allergy, 5: 1 (1958).

16. Payne, D. M., Porter, D. W., and Gracy, R. W.: Evidence against the occurrence of tissue specific variants and isoenzymes of phosphoglucose isomerase. Arch. Biochem. Biophys., 122: 122 (1972).

17. Ruddle, F. H.: Linkage analysis in man by somatic cell hybrids. Nature, 242: 165 (1973)

18. Staal, G. E. J., Akkerman, J. W. N., Eggermont, E., and Van Biervliet, J. P. G. M.: A new variant of glucose phosphate isomerase deficiency: GPI 
Kortrijk. Clin. Chim. Acta, 78: 121 (1977).

19. Van Biervliet, J. P. G. M., and Staal, G. E. J.: Excessive glycogen storage in glucose phosphate isomerase deficiency. Acta Paediat. Scand., 66: 311 (1977).

20. Van Biervliet, J. P. G. M., Vlug, A., Bartstra, H., Rotteveel, J. J., De Vaan, G. A. M., and Staal, G. E. J.: A new variant of glucose phosphate isomerase deficiency. Humangenetik, 30: 35 (1975).

21. Van Biervliet, J. P. G. M., Van Milligen-Boersma, L., and Staal, G. E. J.: A new variant of glucose phosphate isomerase deficiency (GPI Utrecht). Clin. Chim. Acta, 65: 157 (1975).

22. Vives-Corrons, J. L., Rozman, C., Kahn, A., Carrera, A., and Triginer, J.
Glucose phosphate isomerase deficiency with hereditary hèmolytic anemia in a Spanish family: Clinical and familial studies. Human Gener., 29: 291 (1975).

23. This work was supported by Grant CRL 76-5-110 from INSERM. We are very grateful to Mrs. M. Urbanek for the typing of the manuscript.

24. Requests for reprints should be addressed to: A. Kahn, M.D., Ph.D., Institut de Pathologie Moléculaire, 24, rue du Faubourg Saint-Jacques 75014 Paris (France).

25. Received for publication February $8,1977$.

26. Accepted for publication March 15, 1977.
Antigen complement fixation creatinine

\title{
Quantitation of Renal Antigen Excretion in the Urine of Normal Children and of Children with Various Renal Diseases. I. Quantitation of Renal Antigens in Random Urine Samples
}

\author{
E. GAZIT, Y. ROTEM, AND H. BOICHIS ${ }^{(27)}$ \\ Department of Pediatrics "C," Department of Pediatrics "B," and the Pediatric Renal Unit, Chaim Sheba Medical \\ Center, Tel Hashomer and Sacker School of Medicine, Tel-Aviv University, Tel-Aviv, Israel
}

\section{Summary}

This study reports a serologic method for the measurement of kidney-derived antigens in the urine of healthy children and of children with renal diseases. Two hundred twenty patients were studied. Four groups were recognized: group $A$, patients with no evidence of renal disease; group $B$, patients with past history of active urinary tract infection; group $C$, patients with active urinary tract infection; group $D$, patients with other renal diseases.

Urinary renal antigen concentration was tested by the complement fixation method, in which titers of antigens in the urine were compared with a standard human renal antigen extract. The distribution of renal antigen concentrations in group $C$ differed significantly $\left(P\left(\chi^{2}\right)\right.$ less than 0.001$)$ from the other three groups. About $85 \%$ of patients in groups $A, B$, and $D$ had levels below $0.6 \mathrm{mg} / \mathrm{ml}$, whereas in group $C$ only $53 \%$ of patients had similar concentrations. After factoring the results by the urinary concentration of creatinine, $85 \%$ of patients in group $C$ had antigen levels above $0.6 \mathrm{mg} / \mathrm{ml}$ as opposed to $24 \%, 44 \%$, and $27 \%$ in groups $A, B$, and $D$, respectively. The results of the study are consistent with the assumption that the rate of discharge of renal antigenic material in the urine is accelerated in certain renal diseases.

\section{Speculation}

Titers of renal antigen in urines of patients with urinary tract infection may differentiate parenchymal disease from lower tract disease. Monitoring of the pattern of renal antigen excretion may provide an index for optimal duration of antibacterial therapy in pyelonephritis.

Investigators have long been trying to find satisfactory methods for the assessment of the activity of renal diseases and the extent of ongoing organ injury. Indirect criteria such as blood chemistries, various renal functions, intravenous pyelography, and even renal biopsy are not always subtle enough to determine progression of disease.

Attention has recently been focused on the urinary excretion of protein under both normal and pathologic conditions (3). Most of these proteins are derived from the plasma $(2,8)$, although some have been identified as tissue components, of which minute amounts are excreted normally in the urine $(5,9$, 13). In the course of some pathologic conditions and during experimental renal disease, the amount of tissue components in the urine was found to increase markedly $(1,6,17)$. Some of these were identified as having renal antigen specificity. Boss and his collaborators $(5,6,17)$, as well as Antoine et al. (1), concluded that repeated determination of the renal antigens excreted in the urine of a patient might prove of value both as a diagnostic aid and for assessment of prognosis.

This reports a serologic method for the measurement of kidney-derived antigens in the urine of healthy children and of children with renal diseases.

\section{MATERIALS AND METHODS}

\section{PATIENTS}

Two hundred twenty consecutive patients attending the pediatric renal outpatient clinic were studied. They were of both sexes and their ages ranged from 6 months to 12 years. The urine samples were given running code numbers, and their records were referred to only after the completion of the laboratory investigation. Four groups of patients were recognized: group $A$, 80 patients with no evidence of renal disease; group $B, 60$ patients with a past history of urinary tract infection, with or without malformation of the urinary tract, but no evidence of 